\title{
The Pyramid: a typical Marlborough family farm
}

\author{
CHRIS and JULIA DAWKINS \\ Pyramid, Waihopai Valley, Blenheim \\ dawkins.pyramid@xtra.co.nz
}

\begin{abstract}
Summary
Our time from 1978 on the "Pyramid" in the Waihopai Valley is described with particular comments on the benefits gained from the encouragement of land based industries provided by policies of the Muldoon government. The effective area for pastoral farming is 380 ha. Half the farm is clay downs, one quarter stony flats in lucerne and the rest is steep hill. Average rainfall is $760 \mathrm{~mm}$ with a 6 month warm season moisture deficit in most years. Lamb production from 1500 Corriedale cross ewes provides the main income from sheep with only $20 \%$ coming from wool. Cattle are increasingly important with income of $\$ 290 /$ ha/year over the last 2 years. Soil fertility has been lifted to Olsen $\mathrm{P}$ values of 33 , sulphate $\mathrm{S}$ to 12 and $\mathrm{pH}$ to a minimum of 6.0. Greater use of legumes will exploit this high soil fertility to give further improvements in animal performance and allow us to abandon bag $\mathrm{N}$.
\end{abstract}

Keywords: cattle, dryland farming, family farm, lucerne, Marlborough, sheep, subterranean clover

\section{History}

I took up the challenge of farm ownership in 1978 when I purchased the Pyramid from my father for the government valuation of $\$ 186,000$. For the 3 previous years I had been farming in partnership with my father as J.A. Dawkins \& Son, having served a thorough apprenticeship under his guidance and also a brief period at Massey University.

After 23 years at the Pyramid my parents chose to retire into Blenheim. Prior to this, they had farmed for 8 years in Port Gore in the outer Marlborough Sounds. In those post war days it was extremely productive, clean hill country, but access was by sea only from Picton, around Cape Jackson and into the open waters of Cook Strait.

I guess it is all relative to today but my parents thought nothing of walking 3 hours up and over the hill and down into Queen Charlotte Sound to Endeavour Inlet to collect the mail. This provided a good opportunity to remove debris from the telephone line as they walked. With a family of three, the lack of facilities for education, health services and access were all impediments to progress, so in 1954 the decision to move was made, and my father reluctantly bought a farm closer to town.

The Pyramid consists of 415 ha at the confluence of the Avon and Waihopai Rivers in central Marlborough,
$30 \mathrm{~km}$ south-west of Blenheim and $250 \mathrm{~m}$ above sea level at the mail box. Since 1995 I have also been leasing an additional 30 ha contiguous block on an informal, long term basis. This gives 380 ha effective for pastoral farming.

Back to 1978 when I was 23 years old, single, strong and enthusiastic. I was given a wonderful opportunity by my parents when they moved into Blenheim where they purchased a near new three bedroom permanent materials home for $\$ 32,000$. Mother took to town life like a duck to water, but father who was very fit and active had few urban interests so he commuted to and from the farm 7 days a week for another 26 years. This provided an extremely valuable source of knowledge and labour.

The Muldoon government of the day actively encouraged land based industry with numerous subsidies and supplementary minimum prices supporting incomes. Father received a farm vendor mortgage tax concession by having $50 \%$ of the interest earned from money left in the property exempt from income tax.

I benefited from the Livestock Incentive Scheme with an interest free suspensory loan of $\$ 12$ per qualifying stock unit, which was written off after 2 years. An alternative option was a deduction from taxable income of $\$ 24$ per s.u. Stock number increases entered the books at nil value. I think my father had been receiving a $\$ 50$ / ha lucerne establishment grant, but a maximum qualifying area of only 12 ha applied.

Fertiliser was subsidised by $\$ 22.50$ a tonne which I think reduced the price to less than $\$ 80$ a tonne for superphosphate. A bounty also existed on fertiliser spreading, $\$ 8.50$ a tonne for aerial application and $\$ 4.00$ for ground spreading. Lime spreading was, however, subsidised at only $\$ 2.00$ per tonne. Fertiliser and lime transport was subsidised by between 2 cents and 4.4 cents per tonne per $\mathrm{km}$ depending on distance from works, merchant or port, to farm. First year depreciation on new plant, machinery and buildings was $25 \%$ plus a non taxable $40 \%$ investment allowance.

I embraced the Land Development Encouragement Loans and was able to convert 80 ha of unproductive stony native river flat to lucerne at a cost way in excess of the original $\$ 450 /$ ha that I paid for the land. Actually over the next 8 years I borrowed in excess of the initial purchase price of the farm to develop the property; this included reticulated water to all paddocks, fertiliser, 
pasture improvement, sheep yards, cattle yards, wool shed and house renovations. Although by now market interest rates were pushing $22 \%$, I was capped by a Rural Bank concessional rate for development loans at $7 \%$. Stamp duty of around $1 \%$ was written off on a first farm purchase.

Although I continued to milk the house cow, my parents bought milk in one pint glass bottles $(600 \mathrm{mls})$ for 4 cents. Julia was then a student at Training College and Victoria University in Wellington. A ticket on Cook Strait ferry cost $\$ 3$ and a motor vehicle $\$ 1$ per foot, meaning her Morris Mini cost $\$ 10.00$. Budgeting was easy for her in those days, essential items for a student all cost 46 cents - a gallon of petrol, a nip of spirits, a bottle of beer (as in $745 \mathrm{mls}$ ), and a packet of cigarettes. All one had to do was arrange these 46 cents in order of priority.

\section{The Pyramid}

Approximately $50 \%$ of the Pyramid is heavy clay based downs that could be cultivated by a two wheel drive tractor, $25 \%$ stony river flats and terraces and the remaining $25 \%$ steeper hill. Rainfall of $760 \mathrm{~mm}$ per annum is spread evenly on a monthly basis but about 6 months of moisture deficit starts in mid/late October in most years. It is a warm property facing north with 50 light frosts p.a. but minimum $10 \mathrm{~cm}$ soil temperature at the house seldom drops below $3^{\circ} \mathrm{C}$. Mean average summer (Dec, Jan, Feb) air temperature is $19^{\circ} \mathrm{C}$, dropping to $8^{\circ} \mathrm{C}$ in the winter (Jun, Jul, Aug). Prevailing wind is a nor'wester, but the property is not particularly windy. Annual pasture production is approximately $7000 \mathrm{~kg}$ $\mathrm{DM} / \mathrm{ha}$. This consists of about $4.5 \mathrm{t}$ on the hill, $7 \mathrm{t}$ on the downs and $10 \mathrm{t}$ from lucerne.

Thirty years ago my plan was to develop the farm by making best use of each of the three main zones and then integrate all areas together. Lucerne was the species of choice on the free draining river flats and that has never changed, comprising $20 \%$ of total grazing area of the farm. It has always been grazed in situ by hoggets and their lambs in spring, along with ewes rearing triplets. This lucerne then provides valuable summer feed for hoggets and two tooths with the two tooths being mated on the flats during the autumn, and sometimes the hoggets as well.

The clay downs provide valuable flushing and tupping feed as they retain moisture well into the early summer and respond quickly to autumn rains, thus providing a bank of feed for winter. I have always had a phobia about endophyte, hence no high endophyte ryegrass has been used. Initially I cultivated and sowed the clay country into fescue based perennial pasture mixes. I was a poor manager of fescue in spite of my best intentions and it failed to persist for more than 5 or 6 years.
With the advent of the novel endophytes I have converted to ryegrasses with AR1. These also have a question mark over their longevity but provide good results in terms of animal performance. With my own direct drill it is a relatively straight forward exercise to chop and change pasture species and cultivars. Annual and short rotation ryegrasses have proven to be very productive, especially during our relatively mild winters.

The steeper country has been used more as a run off, but does have an important role to play, particularly when complementing the lucerne terraces and flats. Sub clover content and consequently total productivity could be increased by more intensive sub division and grazing of the hill.

All the grass species that I have sown over the years have made valuable contributions to the productivity of the farm (tall fescue, phalaris, prairie grass, annual and perennial ryegrasses and cocksfoot). Lucerne and sub clover are a godsend but other clovers have been more challenging with either establishment or persistence (Caucasian, white, red, and balansa). The herbs, chicory and plantain, are well liked by the animals.

Approximately $13 \%$ of total land area has been retired from grazing and planted in recognised timber trees, predominately radiata pine. This land is mainly eroding steep northerly faces, river banks, stream margins and other fragile areas of minimal grazing value. Eight ha of regenerating natives on the Avon river bank is protected by a QEII covenant. These tree blocks and their shelter effects have enhanced carrying capacity on the property and are now adding an extra income stream in addition to the normal sheep meat, wool and cattle. Approximately 1000 tonnes of logs could be harvested on an annual basis now, with the first 3000 tonnes having been sold in autumn 2007.

\section{Livestock}

I have always attempted to farm within the constraints of our climate and have never attempted to fight it. Consequently the 140 breeding cows that I purchased with the farm in 1978 only made it through to the first serious drought. The $1 / 4$ Hereford, $1 / 4$ Angus, $1 / 2$ Friesian cows mated back to a European terminal sire were outstanding performers - weaning calves at $300 \mathrm{~kg}$. However the feed demands of a lactating cow over our prolonged dry summers meant they were too difficult to keep in the system. Cattle policy now revolves around trading, wherever there is an adequate margin, so we will go anywhere and we have done it all. At the moment dairy support tends to dominate with carry-over cows, supplying in calf heifers and also breeding bulls grown out from weaners.

The climate is tailor made for sheep breeding and finishing and so a reasonably stable flock of 1500 ewes 
Figure 1 Wool as a percentage (\%) of total farm income at Pyramid for 29 years from 1978/79 to 2006/07.

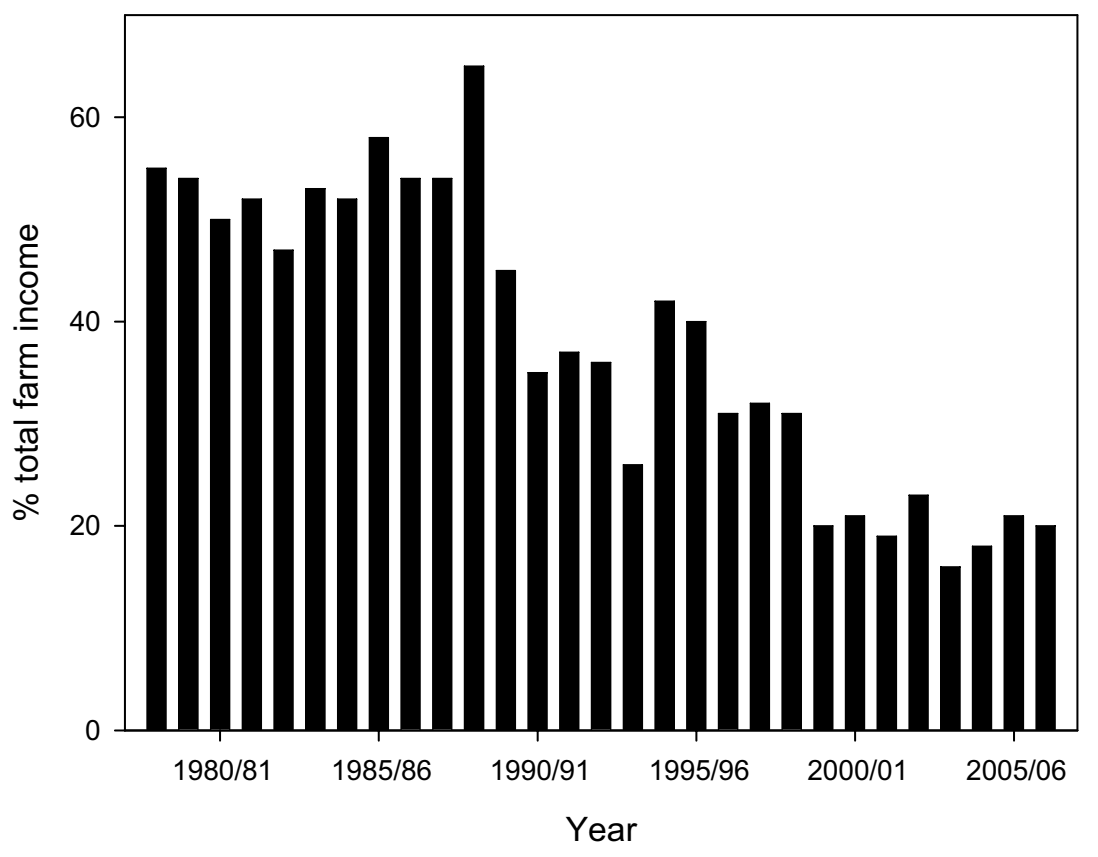

Figure 2 Total carcass weight (kg/year) of lambs sold from Pyramid from 1992/93 to 2007/08.

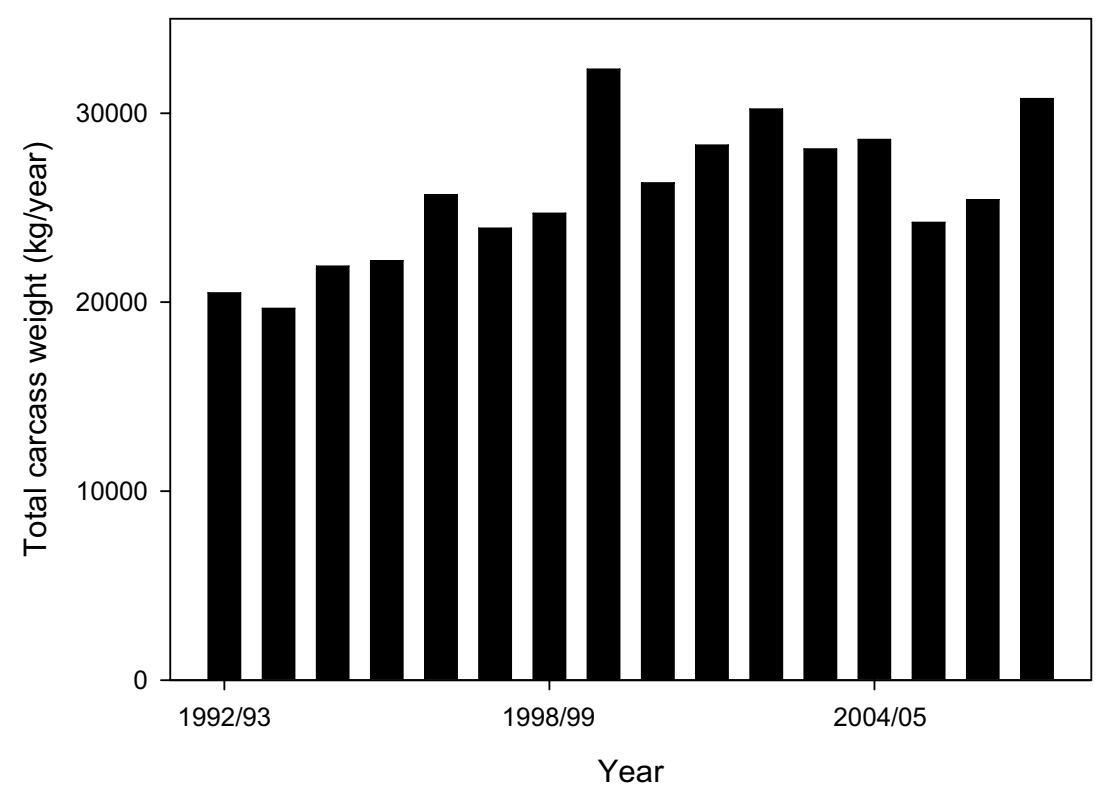

and 500 replacements is run in conjunction with the trading cattle that take advantage of feed surpluses. Cattle numbers can vary between zero and 500 depending on the season and available feed. Of late, cattle returns have exceeded those of the sheep and hence we have tended to push the cattle numbers a little. With this frequent change in the mix of livestock it can be confusing and difficult to measure progress in terms of animal production gains. This problem applies particularly to the cattle enterprise where classes of stock differ greatly from year to year. However, cattle income gives an indication of their importance. Over the last 10 years, cattle income has ranged from \$327/ha (2003) down to \$115/ha in 1999 . Most recently in 2006 and 2007, we have averaged \$290/ 
Figure 3 Average sale price (\$/head) of lambs (prime and store) sold from Pyramid from 1992/93 to 2007/08.

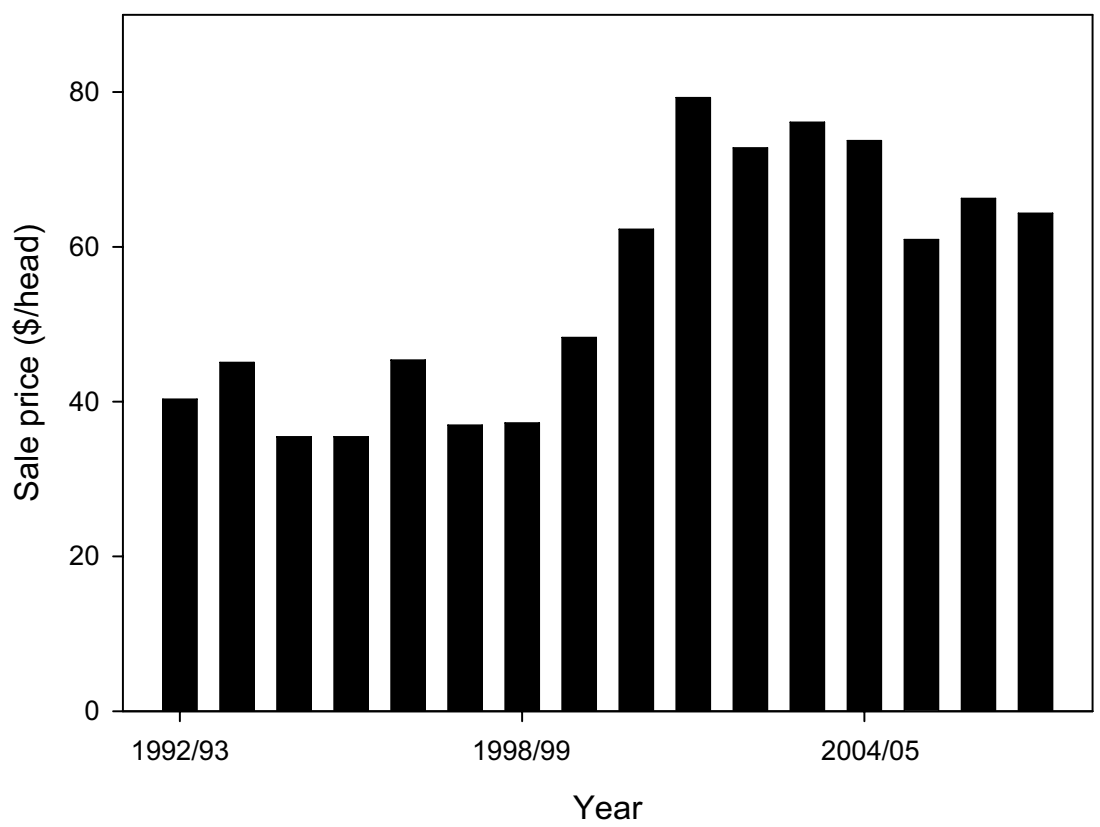

ha/year from cattle.

The big framed Corriedale and Corriedale cross ewes are designed to maximise lamb growth rates up to weaning. The bulk of the lambs need to be dead by Christmas given our summer heat. Emphasis has been placed on weight of lambs at 12 weeks of age at weaning in the third week of November. Hybrid vigour is exploited with $40 \%$ of ewes first cross and mated back to Suffolk and Poll Dorset terminal sires. Average sheep performance over the first 2 years of the current Monitor Farm programme (2006 and 2007) indicates good lamb growth rates of $325 \mathrm{~g} / \mathrm{d}$ pre- and $300 \mathrm{~g} / \mathrm{d}$ post-weaning and 90 day weaning liveweight of $34 \mathrm{~kg}$. While the weaning percentage during this period has only improved from $135 \%$ to $137 \%$, lamb loss between scanning and tailing has improved significantly. Lamb loss in 2007 was $18 \%$, about average for Marlborough, compared to $28 \%$ in 2006. A significant contributor to lamb loss had been ewe loss which was $7 \%$ in $2004,6 \%$ in 2005 , and $4.3 \%$ in 2006 . In 2007 , changes in ewe management were put into place to ensure the flock did not consist of very high condition score multiple bearing ewes losing condition in late pregnancy. The end result of this was a very acceptable ewe loss of only $1.6 \%$. Further efforts are being made to reduce the lamb loss.

Figure 1 shows the decline in wool income as a proportion of total sheep income from the late 1970s to $2006 / 07$. From the late 1970 s to $1988 / 89$ wool income averaged over $50 \%$, during 1990 s over $30 \%$ but this century only $20 \%$ of total sheep income. Figure 2 shows total lamb carcass weight sold from the Pyramid from 1993 to 2008. Cattle numbers, rainfall and the extra 30 ha leased in 1995 have all influenced lamb meat production but performance has also improved. While total lambs sold prime have averaged 1600/year from 1995/96 to 2007/08 (range 1400 to 1960), carcass weights have increased from $15.2 \mathrm{~kg}$ (1995/96 to 1998/99) to $17.2 \mathrm{~kg}$ since 2001/02. The average price/head of lambs sold from the Pyramid was $\$ 34.50$ from 1992/93 to 1999 / 2000 and has averaged $\$ 69.47$ from 2000/01 to 2007/08 (Fig 3).

Animal health issues are minimal with ewe lambs/ hoggets normally only drenched twice, once at weaning and once again the following autumn or winter. Adult ewes are not drenched and I aim to maintain a healthy natural immune system within the flock through attention to nutritional requirements.

\section{Pasture Management}

Meat and Wool New Zealand Pasture Plan recordings highlight the fact that $65 \%$ of total annual dry matter yield is produced during 10 weeks in spring. Pasture control can be compromised when grasses go reproductive in late spring/early summer, but the clay downs country can be mown and rank seed head bailed as hay. Although of low quality, it helps balance the diet of dairy cows on winter green feed brassica crops. Providing it has rained, the resulting mown paddock is then well groomed for late summer feeding prior to ewe mating with fresh leaf, and no dead material carrying 
fungal toxins. A ready market also exists on the West Coast with dairy farmers paying a reasonable price for big bales of our pasture toppings.

A reserve of high quality lucerne hay is bought in for a "mother of all droughts." My usual ration for getting through a limited feed pinch period is ryegrass pasture baleage. What is left of this can be sold in late winter to a neighbour.

\section{Contribution of Technology}

Electric fencing, feed quality analysis and feed budgeting, direct drilling, livestock weighing systems, faecal egg counts (FEC), ultra sonic pregnancy scanning, novel endophytes and feed conservation systems have all been taken up with enthusiasm. Although I look upon machinery as a necessary evil the advent of the fourwheeled motorbike has certainly simplified access and mobility.

With the exception of ultra sonic pregnancy scanning, novel endophytes and feed conservation systems (particularly baleage), most of these technologies were in existence 30 years ago. It is the development and improvement of these aids that have made an impact. For instance, I can put sheep dung samples in my rural delivery mail box at $1.00 \mathrm{pm}$ Monday afternoon and have the FEC results back at lunchtime the next day, and I use service providers in either Dunedin or Whangarei.

Electric fence system progress since the mid 1970s has simplified animal management to such an extent that my youngest son cannot understand how we could have possibly farmed without polywire and plastic stakes. I am somewhat of a control freak on farm. All animals have to be in the right mob at the right time and fed accordingly. The annual ultrasonic pregnancy scanning is therefore one of the many highlights of the year. We are blessed in Marlborough with arguably the most experienced and proficient sheep pregnancy scanner in New Zealand.

With a better understanding of weed and pest control, direct drilling is now an accepted part of pasture and crop establishment. Some costs have moved to our advantage. I can recall paying over $\$ 30 / \mathrm{L}$ for Roundup in the mid-1980s compared with my last drum of glyphosate costing less than $\$ 5.00 / \mathrm{L}$. Recent substantial increases in the cost of some agrichemicals have unfortunately eroded those gains.

Feed planning and feed budgeting has been reduced to the ability of my then 10-year-old son. The year of 2000 commenced with a particularly dry summer, the carry over from a dry spring. We were hand feeding ewes 13 MJME per head per day based on feed test analysis results on baleage, lucerne hay, and industry figures for peas. With the aid of the cattle weighing platform and load bars, my son was quite capable of determining the daily ration of DM required for each mob.

I was forced into weighing animals prior to slaughter many years ago after a neighbour finished the year with export sale lambs $1 \mathrm{~kg}$ carcass weight lighter than my own yet $\$ 1.50$ per head more valuable, in spite of selling at the same time of year. We draft and weigh much more frequently now and in smaller mobs. It has been a long time since we sent out a complete truck and trailer unit load of lambs.

Drought proofing the farm has been a very satisfying experience for me, and there is nothing better than a decent dry summer to test the system. Prolonged periods of moisture deficit are quite manageable with the aid of:

- Early warning systems and climate predictions such as those that Ian Blair provides

- Flexible live stock policy - especially cattle

- Drought tolerant pastures that might not necessarily produce a lot in a dry summer, but they do survive and bounce back after it finally does rain. Species which are best adapted to summer droughts are the Mediterranean fescues, lucerne, cocksfoot and subterranean clover.

- Supplementary feeds and conservation systems, particularly baleage in our situation. The advent of big bales has created opportunities that did not previously exist and it is quite practical to have 1 year's supply of baleage and at least 2 years of lucerne hay. The hay is bought in as I prefer to graze my lucerne stands in situ.

\section{Fertiliser}

1978 soil test results were: Olsen P 4, sulphate S 5, but $\mathrm{pH}$ was not too bad at 5.9. Since then we have been consistent and regular fertiliser users every year, to the extent we have been accused of wasting the stuff during our current period as Monitor Farmers (2006/08). Given the recent superphosphate price increases from $\$ 158$ / tonne in 2004 to the current price of $\$ 487 /$ tonne, I am pleased we now have Olsen P levels of 33; sulphate S values no lower than 12 and the lowest $\mathrm{pH}$ being the hill blocks at 6.0. In excess of $1600 \mathrm{t}$ of lime have been applied since 1978, averaging $55 \mathrm{t}$ per annum.

Urea is used strategically during the autumn to help build up a bank of feed for winter. It was a tool that worked well when we were encouraging the fescue on the clay downs to tiller in the autumn, so the practice has been carried on. Throwing the selenium prills on top of the annual fertiliser in the super bin gives outstanding results in terms of raising the selenium status of livestock, according to Optigrow tests for liver minerals.

\section{The Future}

In the short term we shall have to adjust to the rapid increases in the price of farm inputs. Fortunately our soil 
fertility is high so savings may be made there but we will need to monitor the soils in the longer term. We will continue to strive to increase ewe efficiency by weaning more lambs per ewe while maintaining or improving the rate of lamb liveweight gain. However, ewe numbers will be kept at 1500 and any increase in total feed produced will be eaten by more cattle.

Animal performance will be improved by increasing legume production on the hill area with sub clover. The ability of lucerne to persist on the better drained clay downs paddocks will be tested and late flowering arrowleaf clover may be included in dairy support forage rotations between permanent pasture. The increased emphasis on legumes will get more nitrogen coming into the total farm system through biological $\mathrm{N}$ fixation. Bag nitrogen costs should then be zero.

In the medium term it may be possible to achieve carbon neutral status by increasing the area planted in trees. It will be interesting to see where the goal posts are placed in this regard once agriculture is included in the carbon trading game.

However, the big issue hanging over our farm is the march of grapes up the Waihopai Valley. The grape monoculture is having a profound effect on pastoralism in the lowlands of Marlborough but in the longer term market forces tend to dominate lifestyle preferences. 